\title{
The influence of electron beam radiation in the nutritional value, chemical composition and bioactivities of edible flowers of Bauhinia variegata L. var. candida alba Buch.-Ham from Brazil
}

\author{
Anna L.C.H. Villavicencio ${ }^{\mathrm{a}, \mathrm{b}}$, Sandrina A. Heleno ${ }^{\mathrm{a}}$, Ricardo C. Calhelha ${ }^{\mathrm{a}}$, \\ Celestino Santos-Buelga ${ }^{c}$, Lillian Barros ${ }^{\mathrm{a}}$, Isabel C.F.R. Ferreira ${ }^{\mathrm{a}, *}$ \\ a Centro de Investigação de Montanha (CIMO), ESA, Instituto Politécnico de Bragança, Campus de Santa Apolónia, 5300-253 Bragança, Portugal \\ b Nuclear and Energy Research Institute, National Commission of Nuclear Energy, IPEN/CNEN-SP, Av. Professor Lineu Prestes 2242, Butantã, 05508-000 São Paulo, \\ Brazil \\ c GIP-USAL, Facultad de Farmacia, Universidad de Salamanca, Campus Miguel de Unamuno, 37007 Salamanca, Spain
}

\section{A R T I C L E I N F O}

\section{Keywords:}

Bauhinia variegata L. var. candida alba Buch.-

Ham

Electron beam radiation

Nutritional value

Chemical composition

Bioactivity

\begin{abstract}
A B S T R A C T
As edible flowers are highly perishable, irradiation technology can be applied to increase their shelf life, as also for phytosanitary purposes. Herein, flowers of Bauhinia variegata L. var. candida alba Buch.-Ham were submitted to electron beam irradiation at the doses of $0.5,0.8$ and $1 \mathrm{kGy}$, to study the effects in the nutritional and chemical profiles, and also in antioxidant, cytotoxic and anti-inflammatory activities. The petals of white flowers revealed interesting bioactive properties being kaempferol derivatives the most abundant compounds, especially kaempferol-3-O-rutinoside. The applied irradiation doses did not highly affect the nutritional profile. No changes were produced in cytotoxicity, but the anti-inflammatory activity slightly decreased. However, the antioxidant activity was increased, especially in the dose of $0.5 \mathrm{kGy}$, in agreement with the higher content in phenolic compounds found at this dose.
\end{abstract}

\section{Introduction}

In the art of cooking, flowers have been increasingly used all around the world for several cultures and for many purposes, becoming a common practice, by providing better sensorial and nutritional quality to foodstuff, in addition to an attractive visual appearance (Koike et al., 2015a; Mlcek \& Rop, 2011). Beyond these attractive characteristics, several edible flowers are also rich in different nutrients and bioactive compounds such as proteins, carbohydrates, sugars, organic acids, terpenoids, carotenoids, flavonoids and vitamins (Mlcek \& Rop, 2011). Due to the presence of bioactive compounds, especially flavonoids, edible flowers are also described as having different bioactivities such as antioxidant (Kumar, Bhandari, Singh, \& Bari, 2009), antihypertensive (Xie \& Zhang, 2012), antibacterial (Ammar et al., 2015), or antitumor (Sagdic et al., 2013), among others.

Bauhinia variegata L var. candida alba Buch.-Ham white flowers are edible and commonly known as cow's foot due to their unique and characteristic aspect. These flowers belong to the Fabaceae family, and are native from Asia. Other Bauhinia species with white flowers such as B. forficata have been described has having different bioactive properties, especially against Diabetes mellitus (da Cunha et al., 2010), being the leaves extensively used as an antidiabetic in the folk medicine (Volpato, Damasceno, Rudge, Padovani, \& Calderon, 2008). Beyond the mentioned bioactivity, $B$. forficata has also strong antioxidant properties, due to the presence of the glycosides kaempferol and quercetin $O$ glycoside isolated from the leaves (Pinheiro, Johansson, Pizzolatti, \& Biavatti, 2006).

Nevertheless, these flowers are highly perishable, suffering oxidation and being easily contaminated by insects that compromise the integrity of the nutrients and the bioactive compounds present, which also decreases their attractiveness.

The irradiation technology has been used to overcome these problems and has been applied to foodstuff for decontamination, preserving the food characteristics and quality and thus increasing the shelf life of the products, being recognized by important authorities such as the World Health Organization - WHO, International Atomic Energy Agency - IAEA, and Food Agriculture Organization - FAO (Farkas \& Mohácsi-Farkas, 2011). Brazil has a food irradiation regulation that allows the irradiation of any food product in compliance with the Codex Standard (Roberts, 2016). At the moment, in Brazil, the

\footnotetext{
* Corresponding author.

E-mail address: iferreira@ipb.pt (I.C.F.R. Ferreira).
} 
gourmet application to edible flowers is growing and the regulation about irradiation as a phytosanitary treatment to promote the increase in the flowers shelf life is well established. As described by different authors, insect disinfestations by ionizing radiation processing of fresh vegetables, as it concerns of quarantine applications, in some cases is necessary, and the efficacy against the pest and prevention of damage to the fresh commodity provides safe solutions (Ehlermann, 2016; Hallman, 2017).

Lakner, Soos, Vida, and Farkas (2016) reported that in the second half of the 20th century the research in food irradiation application as a preservation method became a new and prospective field of food science and technology following the efforts of Josef Farkas, that made a real bridge between different groups of academic fields, scientists, contributing not just to an enhancement of the knowledge, but also to the proliferation of this path-breaking technology. In a recent report about the Pacific Region and Asia, irradiation is indicated as an environment friendly method for food preservation, as an efficient and safe phytosanitary treatment alternative to the use of chemicals against insects pests (Ihsanullah \& Rashid, 2017). Concerning the consumers acceptance, it is time to educate and inform them about the safety and benefits of using irradiation technology in foodstuff (Ehlermann, 2016; Roberts, 2014). With the publication of secure information regarding the irradiation processes, the consumers are more enlightened about the subject and their acceptance towards the irradiated foodstuff is more favourable (Koike et al., 2015a).

In the present study, a mix of petals, stamens and carpel of white flowers of $B$. variegata $\mathrm{L}$. var. candida alba Buch.-Ham were submitted to electron beam irradiation applying different doses (0.5, 0.8 and $1 \mathrm{kGy}$ ). Furthermore, control samples (non-irradiated) and irradiated samples were studied for their nutritional value, detailed chemical composition, and antioxidant, cytotoxic and anti-inflammatory activities in order to evaluate the irradiation effects in these parameters.

\section{Materials and methods}

\subsection{Samples}

Samples of fresh flowers of B. variegata L. var. candida alba Buch.Ham were collected in São Paulo (Brazil) in the autumn of 2015. The chosen species were described by Lorenzi and Matos (2002). Brazilian orchid-tree, also known as "pata-de-vaca", produces white flowers of extreme beauty, robust appearance and edible appeal, being extensively cultivated in Brazil. It has a raceme of flowers with corolla with five oval-elongated white petals, flowering from June to September.

The white fresh flowers samples were collected at a special reserve in São Paulo University (Brazil), and were further labelled and identified with its respective protocol at Nuclear and Energy Research Institute (IPEN-CNEN/SP), Brazil. The samples were divided into four groups: sample 1 control (non-irradiated, $0 \mathrm{kGy}$ ), sample 2 (0.5 kGy), sample 3 (0.8 kGy) and sample 4 ( $1 \mathrm{kGy})$.

\subsection{Electron beam irradiation}

The irradiation process was performed at the Nuclear and Energy Research Institute - IPEN-CNEN/SP (São Paulo, Brazil), using an electron beam accelerator (Dynamitron, Radiation Dynamics Inc., Edgewood, NY, USA) and following a procedure reported by Koike et al. (2015a, 2015b). The Flowers samples were irradiated using the doses of $0.5 \mathrm{kGy}$ (dose rate: $1.11 \mathrm{kGy} / \mathrm{s}$, energy: $1.400 \mathrm{MeV}$, beam current: $0.3 \mathrm{~mA}$, tray speed: $6.72 \mathrm{~m} / \mathrm{min}$ ), $0.8 \mathrm{kGy}$ (dose rate: $1.78 \mathrm{kGy} / \mathrm{s}$, energy: $1.400 \mathrm{MeV}$, beam current: $0.48 \mathrm{~mA}$, tray speed: $6.72 \mathrm{~m} / \mathrm{min}$ ) and $1.0 \mathrm{kGy}$ (dose rate: $2.23 \mathrm{kGy} / \mathrm{s}$, energy: $1.400 \mathrm{MeV}$, beam current: $0.6 \mathrm{~mA}$, tray speed: $6.72 \mathrm{~m} / \mathrm{min}$ ). In order to measure the radiation dose CTA dosimeters for e-beam machines were used. Afterwards, the samples were lyophilized (FreeZone 4.5, Labconco, Kansas City, MO, USA) and kept in a desiccator, protected from light for subsequent use.

\subsection{Chemical composition}

\subsubsection{Nutritional value}

All samples were analysed in terms of macronutrients (moisture, proteins, fat, carbohydrates and ash), according to the AOAC procedures (AOAC, 2016). Crude protein content (Nx6.25) was estimated using the macro-Kjeldahl method; Soxhlet extraction with petroleum ether was used to determine the crude fat content; incineration at $600 \pm 15{ }^{\circ} \mathrm{C}$ was used to measure ash content. Total carbohydrates were calculated by difference and the energetic value was calculated as following: Energy $(\mathrm{kcal})=4 \mathrm{x}(\mathrm{g}$ protein $+\mathrm{g}$ carbohydrate $)+9 \mathrm{x}(\mathrm{g}$ fat).

\subsubsection{Free sugars}

Free sugars were determined by HPLC coupled to a RI detector (Knauer, Smartline system 1000, Berlin, Germany) using the internal standard (IS, melezitose, Sigma-Aldrich, St. Louis, MO, USA) method, as previously described by the authors (Barros, Pereira, Calhelha, et al., 2013). Mobile phase consisted of acetonitrile:water mixture (70:30 v/v, acetonitrile HPLC-grade, Lab-Scan, Lisbon, Portugal) and separation was achieved using a Eurospher 100-5 NH2 column $(4.6 \times 250 \mathrm{~mm}$, $5 \mu \mathrm{m}$, Knauer). The results were recorded and processed using Clarity 2.4 software (DataApex, Prague, Czech Republic).

\subsubsection{Fatty acids}

The fatty acids were identified using a gas chromatographer (DANI1000, Contone, Switzerland) provided with a split/splitless injector and a flame ionization detector (GC-FID at $260{ }^{\circ} \mathrm{C}$ ) operating in the conditions described by Barros, Pereira, Calhelha, et al. (2013). The identification and quantification of the present fatty acids (fatty acid methyl esters (FAME) reference standard mixture 37, Sigma-Aldrich, St. Louis, MO, USA) was achieved by comparing the relative retention times of FAME standard with the ones of the sample' compounds. The results were recorded and processed using CSW 1.7 software (Data Apex 1.7, Prague, Czech Republic).

\subsubsection{Tocopherols}

Tocopherols were determined following a procedure previously described by Barros, Pereira, Calhelha, et al. (2013), using a HPLC system (Knauer, Smartline system 1000, Berlin, Germany) coupled to a fluorescence detector (FP-2020; Jasco, Easton, USA) programmed for excitation at $290 \mathrm{~nm}$ and emission at $330 \mathrm{~nm}$, using the IS (tocol, Matreya, Pleasant Gap, PA, USA) method for quantification. Mobile phase consisted of a mixture of hexane:ethyl acetate (70:30, v/v, hexane and ethyl acetate HPLC-grade, Lab-Scan, Lisbon, Portugal), and chromatographic separation was performed using a Polyamide II column $(250 \times 4.6 \mathrm{~mm}, 5 \mu \mathrm{m}$; YMC, Kyoto, Japan). The results were recorded and processed using Clarity 2.4 software (DataApex, Prague, Czech Republic).

\subsubsection{Organic acids}

Organic acids were determined by ultra-fast liquid chromatography (UFLC) (Shimadzu 20A series UFLC, Shimadzu Corporation, Kyoto, Japan) coupled to a diode-array detector (DAD) operating in the conditions described by Barros, Pereira, and Ferreira (2013). The compounds were identified and quantified by comparing the area of sample' peaks recorded at $215 \mathrm{~nm}$ with calibration curves obtained from commercial standards (Sigma-Aldrich, St. Louis, MO, USA). The results were recorded and processed using LabSolutions Multi LC-PDA software (Shimadzu Corporation, Kyoto, Japan).

\subsubsection{Phenolic compounds}

Extracts were prepared by macerating the lyophilized flower sample, with a stirring agitation at $150 \mathrm{rpm}$, using ethanol:water (80:20, v/v, $40 \mathrm{~mL}$ ) at $25^{\circ} \mathrm{C}$ during $1 \mathrm{~h}$, afterwards, the samples were filtered (Whatman No. 4 paper) (Koike et al., 2015a). The residue was 
Table 1

Proximate composition, free sugars and fatty acids identified in B. variegata L. var. candida alba Buch.-Ham flowers (mean \pm SD).

\begin{tabular}{|c|c|c|c|c|}
\hline Proximate composition (g/100 g dw) & 0 kGy & $0.5 \mathrm{kGy}$ & $0.8 \mathrm{kGy}$ & $1 \mathrm{kGy}$ \\
\hline Ash & $5.03 \pm 0.06^{\mathrm{a}}$ & $5.1 \pm 0.1^{\mathrm{a}}$ & $5.00 \pm 0.2^{\mathrm{a}}$ & $5.0 \pm 0.1^{\mathrm{a}}$ \\
\hline Carbohydrates & $77.1 \pm 0.2^{\mathrm{b}}$ & $79.0 \pm 0.2^{\mathrm{a}}$ & $80.2 \pm 0.8^{\mathrm{a}}$ & $81 \pm 1^{\mathrm{a}}$ \\
\hline Proteins & $10.90 \pm 0.05^{\mathrm{a}}$ & $10.01 \pm 0.05^{\mathrm{a}}$ & $10.3 \pm 0.2^{\mathrm{a}}$ & $9.22 \pm 0.04^{\mathrm{b}}$ \\
\hline Fat & $7.0 \pm 0.2^{\mathrm{a}}$ & $5.9 \pm 0.1^{\mathrm{ab}}$ & $4.5 \pm 0.5^{\mathrm{b}}$ & $4.9 \pm 0.5^{\mathrm{b}}$ \\
\hline Energy (kcal/100 g dw) & $415 \pm 1^{\mathrm{a}}$ & $409.3 \pm 0.2^{b}$ & $403 \pm 2^{c}$ & $404 \pm 6^{c}$ \\
\hline \multicolumn{5}{|l|}{ Free sugars $(g / 100 g d w)$} \\
\hline Fructose & $10.7 \pm 0.1^{\mathrm{a}}$ & $10.3 \pm 0.5^{\mathrm{a}}$ & $10.6 \pm 0.3^{\mathrm{a}}$ & $10.3 \pm 0.3^{\mathrm{a}}$ \\
\hline Glucose & $7.2 \pm 0.2^{\mathrm{a}}$ & $6.2 \pm 0.5^{\mathrm{b}}$ & $6.7 \pm 0.2^{\mathrm{ab}}$ & $6.7 \pm 0.4^{\mathrm{ab}}$ \\
\hline Sucrose & $2.19 \pm 0.02^{\mathrm{a}}$ & $1.9 \pm 0.1^{\mathrm{c}}$ & $2.09 \pm 0.01^{\mathrm{b}}$ & $2.15 \pm 0.07^{\mathrm{ab}}$ \\
\hline Total Sugars & $20.0 \pm 0.3^{\mathrm{a}}$ & $18.4 \pm 0.8^{b}$ & $19.4 \pm 0.4^{\mathrm{ab}}$ & $19.1 \pm 0.8^{\mathrm{ab}}$ \\
\hline \multicolumn{5}{|l|}{ Fatty acids (relative percent) } \\
\hline $\mathrm{C} 16: 0$ & $17.8 \pm 0.1^{\mathrm{c}}$ & $19.3 \pm 0.2^{\mathrm{b}}$ & $19.9 \pm 0.1^{\mathrm{a}}$ & $16.0 \pm 0.3^{\mathrm{d}}$ \\
\hline C18:0 & $5.61 \pm 0.01^{\mathrm{b}}$ & $5.13 \pm 0.09^{d}$ & $5.3 \pm 0.1^{\mathrm{c}}$ & $6.34 \pm 0.08^{\mathrm{a}}$ \\
\hline C18:1n9 & $3.21 \pm 0.05^{\mathrm{a}}$ & $2.5 \pm 0.1^{\mathrm{bc}}$ & $2.67 \pm 0.09^{b}$ & $2.49 \pm 0.07^{c}$ \\
\hline $\mathrm{C} 18: 2 \mathrm{n} 6$ & $28.2 \pm 0.2^{\mathrm{d}}$ & $30.28 \pm 0.09^{c}$ & $31.06 \pm 0.01^{\mathrm{b}}$ & $32.9 \pm 0.3^{\mathrm{a}}$ \\
\hline $\mathrm{C} 18: 3 \mathrm{n} 3$ & $22.89 \pm 0.08^{\mathrm{d}}$ & $26.89 \pm 0.04^{b}$ & $27.5 \pm 0.1^{\mathrm{a}}$ & $25.9 \pm 0.3^{\mathrm{c}}$ \\
\hline C22:0 & $8.5 \pm 0.4^{\mathrm{a}}$ & $3.6 \pm 0.2^{\mathrm{b}}$ & $3.4 \pm 0.2^{\mathrm{b}}$ & $2.3 \pm 0.1^{\mathrm{c}}$ \\
\hline SFA & $42.3 \pm 0.3^{\mathrm{a}}$ & $37.68 \pm 0.03^{b}$ & $36.3 \pm 0.2^{\mathrm{c}}$ & $35.1 \pm 0.5^{\mathrm{d}}$ \\
\hline MUFA & $6.21 \pm 0.01^{\mathrm{a}}$ & $4.7 \pm 0.1^{\mathrm{c}}$ & $4.7 \pm 0.1^{\mathrm{c}}$ & $5.7 \pm 0.2^{\mathrm{b}}$ \\
\hline PUFA & $51.4 \pm 0.3^{\mathrm{c}}$ & $57.58 \pm 0.08^{b}$ & $58.9 \pm 0.1^{\mathrm{a}}$ & $59.2 \pm 0.6^{\mathrm{a}}$ \\
\hline
\end{tabular}

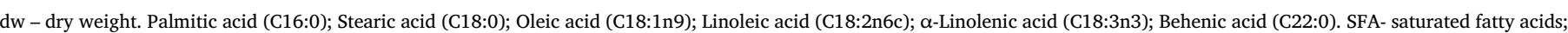

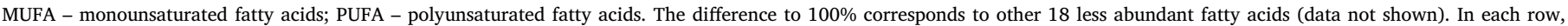
different letters mean significant differences between samples, according to Tukey's HSD test $(\mathrm{p}=0.05)$.

further re-extracted with an additional $40 \mathrm{~mL}$ portion of the ethanol:water $(80: 20, \mathrm{v} / \mathrm{v}, 30 \mathrm{~mL})$ mixture. The combined extracts were evaporated (Büchi R-210, Flawil, Switzerland) to remove the ethanol and the aqueous phase was lyophilized in order to remove the water, obtaining a complete dried residue.

The extracts were dissolved in ethanol/water 80:20 $(v / v)$, filtered through a $0.45 \mu \mathrm{m}$ Whatman syringe filter and transferred to an amber HPLC vial, prior to the HPLC-DAD-MS/ESI analysis. The phenolic compounds were determined using an Hewlett-Packard 1100 from Agilent Technologies, (Santa Clara, CA, USA), equipped with DAD (280, 330 and $370 \mathrm{~nm}$ as preferred wavelengths), and a mass detector (API 3200 Qtrap, Applied Biosystems, Darmstadt, Germany) (Koike et al., 2015a, 2015b). The phenolic compounds were identified by using reported data from literature or by comparison with the available commercial standards (Extrasynthèse, Genay, France). Calibration curves for each available phenolic standard was constructed based on the UV signal for quantification analysis and the results were expressed in $\mathrm{mg}$ per $g$ of extract.

\subsection{Bioactive properties}

\subsubsection{Antioxidant activity}

The extracts descried above in Section 2.3.6, phenolic compounds, were dissolved in ethanol at a final concentration of $50 \mathrm{mg} / \mathrm{mL}$ and successive dilutions were prepared $(0.156-50 \mathrm{mg} / \mathrm{mL})$ in order to be submitted to the following in vitro assays: reducing power by the ferricyanide Prussian blue assay; scavenging activity by the 2,2-diphenyl1-picrylhydrazyl (DPPH, Alfa Aesar, Ward Hill, MA, USA) assay; and lipid peroxidation inhibition by the $\beta$-carotene/linoleate assay, according to Koike et al. (2015a, 2015b). The sample concentrations presenting $50 \%$ of antioxidant activity $\left(\mathrm{EC}_{50}\right)$ or 0.5 of absorbance $\left(\mathrm{EC}_{0.5}\right)$ were obtained using the graphs of antioxidant activity percentages (DPPH and $\beta$-carotene/linoleate assays) or absorbance at $690 \mathrm{~nm}$ (reducing power assay) against sample concentrations. The commercial standard Trolox (6-hydroxy-2,5,7,8-tetramethylchroman-2-carboxylic acid, Sigma-Aldrich, St. Louis, MO, USA) was used as positive control.

\subsubsection{Cytotoxic activity}

Stock solutions of the extracts at $8 \mathrm{mg} / \mathrm{mL}$ were prepared in water and successive solutions were made from 0.005 to $0.4 \mathrm{mg} / \mathrm{mL}$. The cytotoxic activity was determined according to Abreu et al. (2011) using four human tumour cell lines: MCF-7 (breast adenocarcinoma), NCI-H460 (non-small cell lung carcinoma), HeLa (cervical carcinoma) and HepG2 (hepatocellular carcinoma). The cell lines were plated in 96well plates, with a final density of $1.0 \times 10^{4}$ cells/well, and were allowed to attach for $24 \mathrm{~h}$. Then, various extract concentrations were added to the cells and incubated during $48 \mathrm{~h}$. Cells treatment and the Sulforhodamine B assay were performed as described by Abreu et al. (2011). For the toxicity evaluation toward liver cells, a primary cell culture (PLP2) was prepared from a freshly harvested porcine liver; the cells were treated and the toxicity was evaluated through the Sulforhodamine B assay according to a procedure previously established by Abreu et al. (2011). Ellipticine (Sigma-Aldrich, St. Louis, MO, USA) was used as positive control.

\subsubsection{Anti-inflammatory activity}

The extract' solutions tested for the cytotoxic activity were used in the present assay, by using a mouse macrophage-like cell line (RAW264.7) cultured in DMEM medium, supplemented with $10 \%$ heatinactivated fetal bovine serum and L-glutamine, at $37^{\circ} \mathrm{C}$ under $5 \% \mathrm{CO}_{2}$, in humidified air. Cells were detached with a cell scraper, the experimental cell density established in $5 \times 10^{5}$ cells $/ \mathrm{mL}$ and the proportion of cell dead lesser than $1 \%$, according to Trypan blue dye exclusion tests. Then, cells were seeded in 96-well plates at 150.000 cells/well and their attachment to the plate allowed overnight. The cells treatment and the nitric oxide determination were carried out as described by Taofiq et al. (2015). Dexamethasone (Sigma-Aldrich, St. Louis, MO, USA) was used as positive control.

\subsection{Statistical analysis}

For all the experiments three samples were analysed and all the assays were carried out in triplicate. The results are expressed as mean values \pm standard deviation (SD). The differences between the different samples were analysed using one-way analysis of variance (ANOVA) followed by Tukey's honestly significant difference post hoc test with $\alpha=0.05$, coupled with Welch's statistic. This treatment was carried out using SPSS v. 23.0 program. 


\section{Results and discussion}

\subsection{Effects of electron beam irradiation on chemical composition}

The results regarding the proximate composition, free sugars and fatty acids of the control (non-irradiated) and irradiated samples of $B$. variegata L. var. candida alba Buch.-Ham are presented in Table 1.

Carbohydrates were the most abundant macronutrients, followed by proteins, fat and ash contents. The free sugars, fructose, glucose and sucrose were identified and quantified, being fructose the most abundant sugar, followed by glucose and sucrose. Regarding the fatty acids, 24 different molecules were identified, being palmitic, stearic, oleic, linoleic and $\alpha$-linolenic acids the most abundant ones; polyunsaturated (PUFA) predominated over the saturated (SFA) and the monounsaturated (MUFA) fatty acids, due to the high contribution of linoleic and $\alpha$-linolenic acids. As far as we know there are no reports in the literature describing the nutritional profile of a mix of petals, stamens and carpel of B. variegata L. var. candida alba Buch.-Ham.

Regarding the irradiation effects, the ash content was maintained within the increase of the irradiation dose, but slight changes were observed in other parameters: the carbohydrates content was higher in irradiated samples than in the control sample, while the proteins content decreased at $1 \mathrm{kGy}$ that is in line with the results reported by Pereira, Antonio, Rafalski, et al. (2015) for Melittis melissophyllum L. subjected to irradiation process by electron beam irradiation at the same dose. This can be due to the disruption of the ordered structure and the degradation and aggregation of the polypeptide chains of proteins, caused by the formation of oxygen radicals during the irradiation process (Moon \& Song, 2001). The fat content was also lower in irradiated samples, which is in line with the results reported by Pereira, Antonio, Barreira, et al. (2015) for Melissa officinalis L., Melittis melissophyllum L. and Mentha piperita L. The irradiation process did not affect fructose content, while the glucose and sucrose contents slightly decreased specially at dose $0.5 \mathrm{kGy}$, decreasing also the total sugars content. Pereira, Antonio, Rafalski, et al. (2015) reported an increase in the sugars content in Aloysia citrodora Paláu, M. officinalis and M. piperita at the irradiation dose of $1 \mathrm{kGy}$ while for M. melissophyllum the free sugars content decreased. These different results can be due to the different matrices studied but also to changes in the optical rotation, which commonly occur under irradiation treatments (Molins, Motarjemi, \& Käferstein, 2001).

Analysing the results, it can be concluded that SFA and MUFA percentages were higher in control samples, while the opposite was observed for PUFA, which were higher in samples irradiated with the highest doses ( 0.8 and $1 \mathrm{kGy}$ ). The observed results are in agreement with the ones reported by Pereira, Antonio, Rafalski, et al. (2015) for $M$. piperita, who described that SFA decreased and PUFA increased with the application of electron beam radiation up to $1 \mathrm{kGy}$.

The results of tocopherols and organic acids composition are presented in Table 2. The $\alpha$ isoform was the only one found in B. variegata L. var. candida alba Buch.-Ham flowers and did not suffer significant changes with the application of 0.5 and $0.8 \mathrm{kGy}$, but presented a small increase with $1 \mathrm{kGy}$; this is in agreement with the results obtained by Pereira, Antonio, Rafalski, et al. (2015) for A. citrodora, M. melissophyllum and M. piperita, and by Carocho et al. (2012) for chestnuts (Castanea sativa Mill.). This can be due to the stability effect of vitamin E against the irradiation processes (Borges, Gonçalves, de Carvalho, Correia, \& Silva, 2008).

By the analysis of the organic acids, it can be observed that oxalic, malic, ascorbic, citric and fumaric acids were present in the analyzed flowers. The irradiation decreased the amount of oxalic and malic and ascorbic acids in comparison with control samples, which is also in line with the results reported for $A$. citrodora and $M$. officinalis (Pereira, Antonio, Rafalski, et al., 2015), with the exception of $0.8 \mathrm{kGy}$ for ascorbic acid where the amount was maintained herein. However, for citric acid, it was observed an increase in its content with 0.5 and $0.8 \mathrm{kGy}$ (reproducible for results of total organic acids).

The phenolic composition of the samples was characterized as containing phenolic acids and flavonoid glycoside derivatives (Table 3). To the author's best knowledge, there are no reports on the phenolic composition of $B$. variegata L. var. candida alba Buch.-Ham white flowers, although there are some information for flowers, leaves and shoots of other Bauhinia species (da Cunha et al., 2010; Da Silva et al., 2007; Farag, Sakna, El-Fiky, Shabana, \& Wessjohann, 2015; Ferreres et al., 2012; Liu et al., 2016; Marques et al., 2013; Pinheiro et al., 2006; Pizzolatti, Cunha, Szpoganicz, Braz-filho, \& Schripsema, 2003). Among phenolic acids, peaks 2, 4 and 10 were identified as chlorogenic (5-Ocaffeoylquinic acid), caffeic and $p$-coumaric acids, respectively, by comparison of their retention time, UV-vis and mass spectra with commercial standards.

The remaining compounds were all identified as flavonols, mainly quercetin (peaks 1, 12, 13, 15 and 19), kaempferol (peaks 3, 6, 8, 16, 17,18 and 20) and myricetin (peak 9) glycoside derivatives, and flavones, such as apigenin (peaks 5, 11 and 14) and luteolin (peak 7) glycoside derivatives. Compounds 7 (luteolin-6-C-glucoside, homoorientin), 13 (quercetin-3-O-rutinoside, rutin), 14 (apigenin-6- $C$-glucoside, isovitexin), 15 (quercetin-3-O-glucoside, isoquercetin), 17 (kaempferol-3-O-rutinoside, nicotiflorine) and 18 (kaempferol-3-Oglucoside, astragalin) were all identified according to their retention time, mass and UV-vis characteristics by comparison with commercial standards. These compounds have also been reported in other Bauhinia species by some authors (dos Santos et al., 2014; Farag et al., 2015; Ferreres et al., 2012; Liu et al., 2016).

Compound $11\left([\mathrm{M}-\mathrm{H}]^{-}\right.$at $\left.m / z 593\right)$ presented the same pseudomolecular ion and fragmentation pattern as peak 14, thus being identified as apigenin-8-C-glucoside (vitexin). Furthermore, this compound has also been identified in other Bauhinia species (Farag et al., 2015; Liu et al., 2016).

Peaks $3,6,8,16$ and 20 were identified as kaempferol derivatives owing to the product ion observed at $m / z 285$ and UV spectra $\left(\lambda_{\max }\right.$ around $346-350 \mathrm{~nm})$. Peak $3\left([\mathrm{M}-\mathrm{H}]^{-}\right.$at $m / z$ 609) fragmentation pattern indicated that it corresponds to a kaempferol bearing two

Table 2

Tocopherols and organic acids identified and quantified in B. variegata L. var. candida alba Buch.-Ham flowers (mean \pm SD).

\begin{tabular}{|c|c|c|c|c|}
\hline Compound & 0 kGy & $0.5 \mathrm{kGy}$ & $0.8 \mathrm{kGy}$ & $1 \mathrm{kGy}$ \\
\hline \multicolumn{5}{|c|}{ Tocopherols (mg/100 $g \mathrm{dw})$} \\
\hline$\alpha$-Tocopherol & $1.72 \pm 0.04^{b}$ & $1.81 \pm 0.11^{\mathrm{b}}$ & $1.75 \pm 0.06^{\mathrm{b}}$ & $2.06 \pm 0.04^{\mathrm{a}}$ \\
\hline \multicolumn{5}{|c|}{ Organic acids $(\mathrm{g} / 100 \mathrm{~g} d w)$} \\
\hline Oxalic acid & $0.070 \pm 0.001^{\mathrm{a}}$ & $0.057 \pm 0.001^{\mathrm{b}}$ & $0.044 \pm 0.001^{\mathrm{c}}$ & $0.058 \pm 0.001^{\mathrm{b}}$ \\
\hline Malic acid & $1.95 \pm 0.07^{\mathrm{a}}$ & $1.83 \pm 0.02^{\mathrm{ab}}$ & $1.87 \pm 0.04^{\mathrm{ab}}$ & $1.78 \pm 0.04^{\mathrm{b}}$ \\
\hline Ascorbic acid & $0.12 \pm 0.01^{\mathrm{a}}$ & $0.09 \pm 0.01^{\mathrm{c}}$ & $0.14 \pm 0.01^{\mathrm{a}}$ & $0.098 \pm 0.001^{\mathrm{b}}$ \\
\hline Citric acid & $55.94 \pm 0.02^{\mathrm{c}}$ & $61.7 \pm 0.2^{\mathrm{a}}$ & $67.6 \pm 0.4^{\mathrm{a}}$ & $60.1 \pm 0.4^{\mathrm{b}}$ \\
\hline Fumaric acid & $\operatorname{Tr}$ & $\operatorname{Tr}$ & $\operatorname{Tr}$ & $\operatorname{Tr}$ \\
\hline Total organic acids & $58.1 \pm 0.1^{\mathrm{c}}$ & $63.7 \pm 0.3^{b}$ & $69.7 \pm 0.4^{\mathrm{a}}$ & $62.0 \pm 0.4^{\mathrm{b}}$ \\
\hline
\end{tabular}

$\mathrm{dw}$ - dry weight. $\mathrm{Tr}$ - traces. In each row, different letters mean significant differences between samples, according to Tukey's HSD test ( $\mathrm{p}=0.05$ ). 


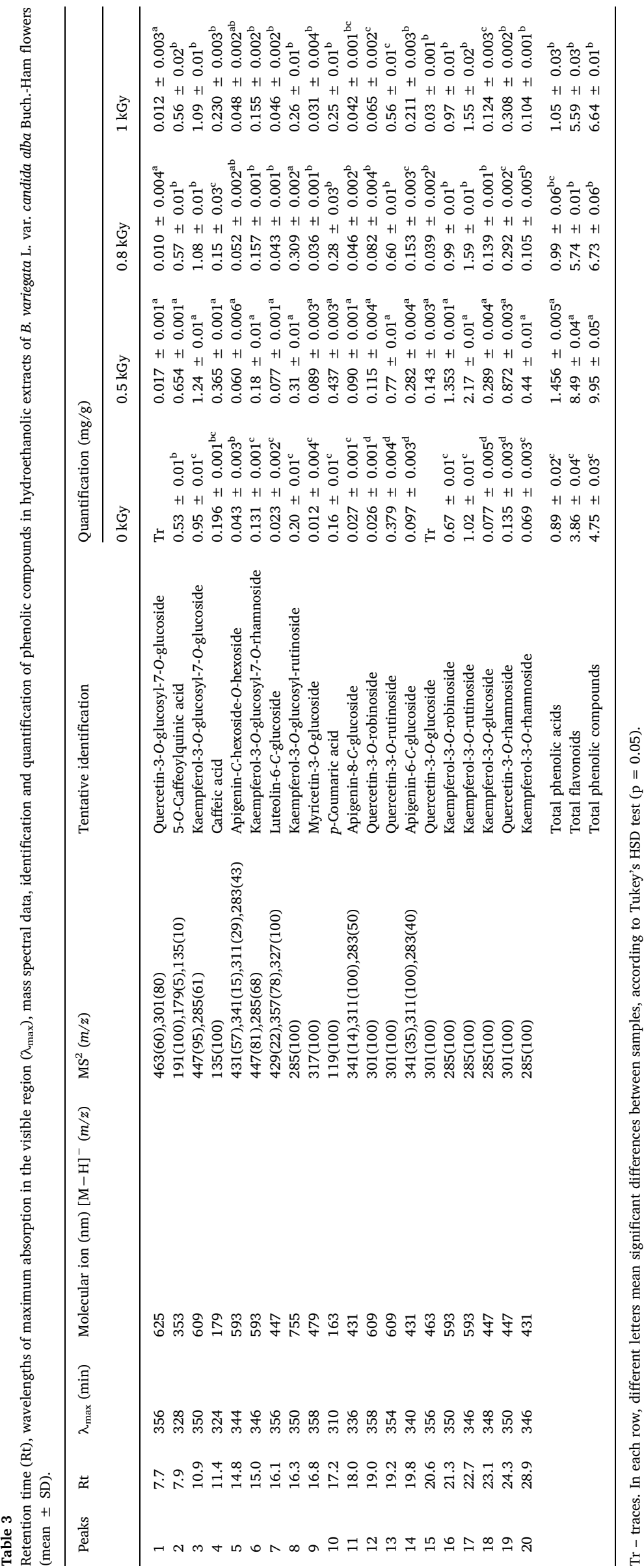


Table 4

Bioactive properties of $B$. variegata L. var. candida alba Buch.-Ham flowers hydroethanolic extracts (mean \pm SD).

\begin{tabular}{|c|c|c|c|c|c|}
\hline & 0 kGy & $0.5 \mathrm{kGy}$ & 0.8 kGy & 1 kGy & Positive control \\
\hline Antioxidant activity ( $E C_{50}$ values $\mu \mathrm{g} / \mathrm{mL}$ ) & & & & & Trolox \\
\hline Reducing Power & $71.2 \pm 0.3^{\mathrm{a}}$ & $59.8 \pm 0.3^{\mathrm{c}}$ & $61.5 \pm 0.3^{\mathrm{b}}$ & $62 \pm 1^{b}$ & $42 \pm 1$ \\
\hline DPPH & $87 \pm 5^{a}$ & $68 \pm 2^{c}$ & $72 \pm 1^{\mathrm{b}}$ & $72 \pm 1^{b}$ & $41 \pm 1$ \\
\hline$\beta$-Carotene bleaching inhibition & $599 \pm 18^{\mathrm{a}}$ & $529 \pm 23^{b}$ & $536 \pm 28^{b}$ & $544 \pm 35^{b}$ & $9 \pm 1$ \\
\hline Cytotoxicity $\left(\mathrm{GI}_{50}\right.$ values $\mu \mathrm{g} / \mathrm{mL}$ ) & & & & & Ellipticine \\
\hline MCF-7 (breast carcinoma) & $159 \pm 13^{\mathrm{a}}$ & $151 \pm 2^{\mathrm{a}}$ & $160 \pm 12^{\mathrm{a}}$ & $156 \pm 9^{\mathrm{a}}$ & $0.91 \pm 0.04$ \\
\hline NCI-H460 (non-small cell lung cancer) & $310 \pm 5^{\mathrm{a}}$ & $295 \pm 19^{\mathrm{a}}$ & $282 \pm 25^{\mathrm{ab}}$ & $258 \pm 14^{\mathrm{b}}$ & $1.03 \pm 0.1$ \\
\hline HeLa (cervical carcinoma) & $71 \pm 8^{\mathrm{a}}$ & $71 \pm 4^{\mathrm{a}}$ & $71 \pm 4^{\mathrm{a}}$ & $75 \pm 8^{\mathrm{a}}$ & $1.91 \pm 0.1$ \\
\hline HepG2 (hepatocellular carcinoma) & $208 \pm 17^{\mathrm{a}}$ & $209 \pm 18^{\mathrm{a}}$ & $217 \pm 2^{\mathrm{a}}$ & $227 \pm 11^{\mathrm{a}}$ & $1.1 \pm 0.2$ \\
\hline PLP2 (non-tumor cells) & $>400$ & $>400$ & $>400$ & $>400$ & $3.2 \pm 0.7$ \\
\hline Anti-inflammatory activity ( $E C_{50}$ values $\mu \mathrm{g} / \mathrm{mL}$ ) & & & & & Dexamethaxone \\
\hline Nitric oxide (NO) production & $235 \pm 11^{\mathrm{b}}$ & $255 \pm 16^{\mathrm{a}}$ & $251 \pm 1^{\mathrm{ab}}$ & $246 \pm 8^{\mathrm{ab}}$ & $16 \pm 1$ \\
\hline
\end{tabular}

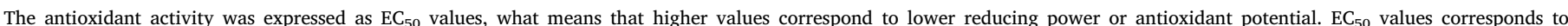

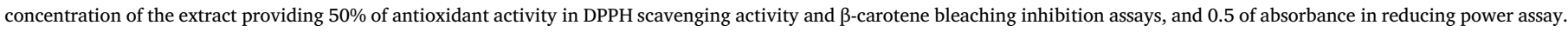

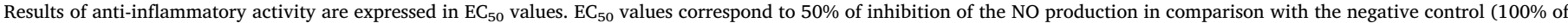

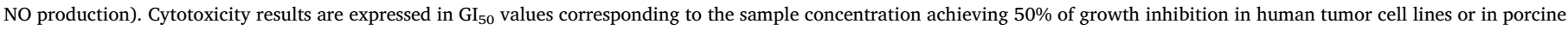
liver primary culture PLP2. In each row different letters imply significant differences, according to Tukey's HSD test ( $\mathrm{p}=0.05$ ).

hexosyl residues. The observation of $\mathrm{MS}^{2}$ fragments at $\mathrm{m} / \mathrm{z} 447$ $(-162 \mathrm{u})$ and $285(-162 \mathrm{u})$, also indicated the alternative loss of each of the hexosyl moieties, respectively, pointing to their location on different positions of the aglycone. To identify the position of substitution, and based in the observation performed by other authors in other Bauhinia species (Farag et al., 2015; Liu et al., 2016), it can be assumed that the positions 3 and 7 as preferential (Ferreres, Llorach, \& GilIzquierdo, 2004), thus this compound was tentatively identified as kaempferol-3-O-glucosyl-7-O-glucoside. Compounds 6 and 16 $\left([\mathrm{M}-\mathrm{H}]^{-}\right.$at $\left.m / z 593\right)$, presented the same molecular ion as compound 17 , bearing a deoxyhexosyl moiety $(-146 \mathrm{u}$ ) from the fragment at $m / z$ 447 and a hexosyl moiety $(-162 \mathrm{u}$ ) from the fragment at $m / z 285$. Two compounds with the same pseudomolecular ion were identified by Ferreres et al. (2012) in leaves samples of B. forficata and by Farag et al. (2015) in 8 examined Bauhinia species (leaf and shoot), and identified as kaempferol-3-O-rutinoside and kaempferol-3-O-robinoside, eluting both simultaneously. Thus, compound 16 could be tentatively identified as the latter compound once kaempferol-3-O-rutinoside corresponded to peak 17, as verified by comparison with a standard. Nevertheless, compound 6 was tentatively assigned as kaempferol-3-O-glucosyl-7-Orhamnoside, taking into account the assumption made for compound 3 about sugar substitution location. Peak $8\left([\mathrm{M}-\mathrm{H}]^{-}\right.$at $m / z$ 755) should correspond to a kaempferol bearing two hexosyl and one deoxyhexosyl residues. The fact that only one $\mathrm{MS}^{2}$ fragment was released corresponding to the aglycone (i.e., $m / z$ at 285 , kaempferol) would suggest that the three sugars constitute a trisaccharide. Moreover, the positive identification of different rutinosides, including kaempferol-3-O-rutinoside, may suggest a rutinosyl identity for the deoxyhexosyl-hexose residue and additionally, it may also be assumed that glucose is the preferred hexose, due to different glucoside derivatives found in this samples, thus this compound was tentatively assigned as kaempferol-3$O$-glucosyl-rutinoside. Peak $20\left([\mathrm{M}-\mathrm{H}]^{-}\right.$at $\left.m / z 431\right)$ was identified as kaempferol-3-O-rhamnoside, taking into account previous findings by Ferreres et al. (2012), Farag et al. (2015) and Liu et al. (2016). Similarly, and taking into account the comments above, compounds 1 $\left([\mathrm{M}-\mathrm{H}]^{-}\right.$at $\left.m / z 623\right), 12\left([\mathrm{M}-\mathrm{H}]^{-}\right.$at $\left.m / z 609\right)$ and $19\left([\mathrm{M}-\mathrm{H}]^{-}\right.$at $\mathrm{m} / \mathrm{z}$ 447) were assigned as quercetin-3-O-glucosyl-7-O-glucoside, quercetin-3-O-robinoside and quercetin-3-O-rhamnoside (quercitrin), respectively. Similarly, peak $9\left([\mathrm{M}-\mathrm{H}]^{-}\right.$at $m / z$ 479) was tentatively identified as myricetin-3-O-glucoside.

Finally, peaks $5\left([\mathrm{M}-\mathrm{H}]^{-}\right.$at $\left.m / z 593\right)$ and $11\left([\mathrm{M}-\mathrm{H}]^{-}\right.$at $\left.m / z 431\right)$ were identified as apigenin derivatives. Peak 11 presented the same fragmentation pattern as compound 14, but eluted earlier and therefore it was tentatively assigned as apigenin-8- $C$-glucoside. Peak $5\left([\mathrm{M}-\mathrm{H}]^{-}\right.$ at $m / z 593)$ released $\mathrm{MS}^{2}$ fragment ions at $m / z 431\left([\mathrm{M}-162]^{-}\right), m / z$ $341\left([\mathrm{M}-162-90]^{-}\right)$and $m / z 311\left([\mathrm{M}-162-120]^{-}\right)$, characteristic of $O, C$-glycosides. This fragmentation pattern allowed identifying peak 5 as apigenin- $C$-glucoside-O-glucoside. To the best of our knowledge $O, C$-glycosides have not been identified in Bauhinia species.

Compounds 3, 16 and 17 corresponded to kaempferol derivatives and were the most abundant compounds in all samples, especially kaempferol-3-O-rutinoside. Several authors reported that kaempferitrin (kaempferol-3,7-O- $\alpha$-dirhamnoside, not identified herein) as a majority phenolic compound present in leaves of other species of Bauhinia, namely B. forficata (da Cunha et al., 2010; Ferreres et al., 2012; Marques et al., 2013; Pinheiro et al., 2006).

In general, irradiation increased the extractability of phenolic compounds. Samples irradiated with $0.5 \mathrm{kGy}$ revealed the highest concentration in phenolic compounds, while samples irradiated with 0.8 and $1 \mathrm{kGy}$ presented similar contents. The increase in phenolic compounds in irradiated samples can be due to a protective effect of irradiation in the atmosphere, by decreasing the $\mathrm{O}_{2}$ content to produce atomic oxygen inside the flowers bags (Koike et al., 2015a). Moreover, extractability increase could also be explained by the capacity of irradiation to break chemical bonds that link polyphenols to other molecules, thereby releasing soluble phenols of low molecular weight and leading to an increase of antioxidant-rich phenolics (Alothman, Bhat, \& Karim, 2009). Koike and co-authors evaluate the dose-response effects of gamma and electron beam irradiation (0.5, 0.8 and $1 \mathrm{kGy})$ of Viola tricolor L. (Koike et al., 2015a) and Tropaeolum majus L. (Koike et al., 2015b), verifying that electron beam was the most efficient technique to be applied at the dose of $1 \mathrm{kGy}$. However, this dose was not the most efficient in the flower samples studied in this work, which showed to be more susceptible to degradation when higher doses are applied.

\subsection{Effects of electron beam irradiation on the bioactive properties}

The results of the antioxidant, cytotoxic and anti-inflammatory activities of the non-irradiated and irradiated samples are presented in Table 4.

B. variegata L var. candida alba Buch.-Ham flowers showed antioxidant activity on the three performed assays, with higher reducing power and DPPH scavenging activity than $\beta$-carotene bleaching inhibition. The DPPH scavenging activity $\mathrm{EC}_{50}$ value obtained is lower (corresponding to a higher activity) than the one reported by Ferreres et al. (2012) for the leaves of other B. forficata L. Bauhinia forficata tea leaves have a strong antioxidant activity evaluated by DPPH assay $(40 \%$ 
inhibition with $40 \mu \mathrm{g}$ of the extract) and reduced iron $\left(\mathrm{Fe}^{2+}\right)$ chelating activity (o-phenantroline method) (60\% inhibition with $40 \mu \mathrm{g}$ of the extract), in an experimental model of hyperglycemia in human erythrocytes (Salgueiro et al., 2013). In another study, aqueous and hydroethanolic extracts of leaves of other species, Bauhinia microstachya (Raddi) Macbr. were evaluated for its antioxidant activity and both extracts revealed strong antioxidant activity, being the ethanolic extract the most effective one; and also a positive correlation was made between the activity and the phenolic content (Da Silva et al., 2007). Other authors studied the antioxidant activity of different species of Bauhinia, being B. forficata, B. variegata, B. variegata var. candida, $B$. galpinii. These authors studied methanolic extracts of leaves of $B$. variegata var. candida and obtained lower antioxidant activity $(300 \mu \mathrm{g} / \mathrm{mL})$ (Farag et al., 2015) than the one obtained in the present study for the same species $(87 \mu \mathrm{g} / \mathrm{mL})$. The irradiation was able to increase the antioxidant activity, especially when applying the dose of $0.5 \mathrm{kGy}$, which is in agreement with the highest concentration of phenolic compounds found in this sample (Table 3). Koike and co-authors reported an increase in the antioxidant activity of $V$. tricolor (Koike et al., 2015a) and T. majus (Koike et al., 2015b) subjected to irradiation treatment, especially at the dose of $1 \mathrm{kGy}$, which also gave the highest amount in phenolic compounds.

Concerning the cytotoxic activity (Table 4), B. variegata L. var. candida alba Buch.-Ham flowers presented cytotoxicity against all the tested tumour cell lines, being more efficient against HeLa cell line, by presenting the lowest $\mathrm{GI}_{50}$ value, followed by MCF-7, HepG2 and, finally, NCI-H460 cell lines. To the best of our knowledge there are no reports regarding the cytotoxic effects of $B$. variegata $\mathrm{L}$. var. candida alba Buch.-Ham flowers. Nevertheless, the effect of a lectin isolated from $B$. forficata was studied and showed strong cytotoxic effects against MCF-7 cells; at 5 and $10 \mu \mathrm{M}$, the extracts were able to cause cells death after 24 and $48 \mathrm{~h}$, respectively (Silva et al., 2014). By analysing the irradiation effects, the applied doses did not significantly affect the activity, except for the NCI-H460 cell line, in which the activity increased with the dose of $1 \mathrm{kGy}$. Moreover, non-irradiated and irradiated samples did not present toxicity for the non-tumour cells PLP2 up to the maximum tested concentration $(400 \mu \mathrm{g} / \mathrm{mL})$.

Regarding the anti-inflammatory activity (Table 4), the studied flowers inhibited the NO production, with increasing activity with the increase of the radiation dose. As far as we know this is also the first report on the anti-inflammatory activity of $B$. variegata $L$. var. candida alba Buch.-Ham flowers.

\section{Conclusion}

In general, electron beam irradiation applied in the doses of $0.5,0.8$ and $1 \mathrm{kGy}$ did not cause remarked effects in the nutritional profile of $B$. variegata $\mathrm{L}$. var. candida alba Buch.-Ham. In what concerns the chemical profile, the dose of $0.5 \mathrm{kGy}$ increased the concentration of phenolic compounds and related antioxidant activity. Although not being also higher the other bioactivities tested (cytotoxic and the anti-inflammatory properties), samples irradiated with this dose maintained the mentioned properties. Overall, by analysing the obtained results, it can be concluded that the application of electron beam irradiation technology can be an efficient methodology to be used in the food industry sector, for preservation and decontamination proposes, without compromising foods integrity in terms of organoleptic, nutritional and bioactive compounds.

\section{Acknowledgments}

The authors are grateful to the Foundation for Science and Technology (FCT, Portugal) and FEDER under Programme PT2020 for financial support to CIMO (UID/AGR/00690/2013), LSRE (Project UID/EQU/50020/2013), S. Heleno (SFRH/BPD/101413/2014). L. Barros and R.C. Calhelha contracts. The authors are also grateful to the
Interreg España-Portugal for financial support through the project 0377_Iberphenol_6_E. IPEN-CNEN/SP/Brd to the National Research Center, CNPq, Brazil for financial support and to the bilateral projectFCT, Portugal/Brazil 2014.

\section{References}

Abreu, R. M. V., Ferreira, I. C. F. R., Calhelha, R. C., Lima, R. T., Vasconcelos, M. H., Adega, F., \& Queiroz, M. J. R. P. (2011). Anti-hepatocellular carcinoma activity using human HepG2 cells and hepatotoxicity of 6-substituted methyl 3-aminothieno[3,2-b] pyridine-2- carboxylate derivatives: In vitro evaluation, cell cycle analysis and QSAR studies. European Journal of Medicinal Chemistry, 46(12), 5800-5806.

Alothman, M., Bhat, R., \& Karim, A. A. (2009). Effects of radiation processing on phytochemicals and antioxidants in plant produce. Trends Food Science and Technology, 20, 201-212.

Ammar, I., Bardaa, S., Mzid, M., Sahnoun, Z., Rebaii, T., Attia, H., \& Ennouri, M. (2015). Antioxidant, antibacterial and in vivo dermal wound healing effects of Opuntia flower extracts. International Journal of Biological Macromolecules, 81, 483-490.

AOAC (2016). AOAC official methods of analysis (20th ed.). AOAC International.

Barros, L., Pereira, E., Calhelha, R. C., Dueñas, M., Carvalho, A. M., Santos-Buelga, C., \& Ferreira, I. C. F. R. (2013). Bioactivity and chemical characterization in hydrophilic and lipophilic compounds of Chenopodium ambrosioides L. Journal of Functional Foods, 5(4), 1732-1740.

Barros, L., Pereira, C., \& Ferreira, I. C. F. R. (2013). Optimized analysis of organic acids in edible mushrooms from Portugal by ultra fast liquid chromatography and photodiode array detection. Food Analytical Methods, 6(1), 309-316.

Borges, O., Gonçalves, B., de Carvalho, J. L. S., Correia, P., \& Silva, A. P. (2008). Nutritional quality of chestnut (Castanea sativa Mill.) cultivars from Portugal. Food Chemistry, 106(3), 976-984.

Carocho, M., Barreira, J. C. M., Antonio, A. L., Bento, A., Kaluska, I., \& Ferreira, I. C. F. R. (2012). Effects of electron-beam radiation on nutritional parameters of Portuguese chestnuts (Castanea sativa Mill.). Journal of Agricultural and Food Chemistry, 60(31), 7754-7760.

da Cunha, A. M., Menon, S., Menon, R., Couto, A. G., Bürger, C., \& Biavatti, M. W. (2010) Hypoglycemic activity of dried extracts of Bauhinia forficata Link. Phytomedicine, 17(1), 37-41.

Da Silva, E. G., Behr, G. A., Zanotto-Filho, A., Lorenzi, R., Pasquali, M. A. D. B., Ravazolo, L. G., ... Moreira, J. C. F. (2007). Antioxidant activities and free radical scavenging potential of Bauhinia microstachya (RADDI) MACBR. (Caesalpinaceae) extracts linked to their polyphenol content. Biological \& Pharmaceutical Bulletin, 30(8), 1488-1496.

dos Santos, P. M., de Almeida, P. D. O., Lima, E. S., de Moraes, M. O., da Costa, P. M., Meira, A. S., \& Junior, V. F. da V. (2014). Perfil de flavonoides e avaliação do potencial antioxidante e citotóxico de Bauhinia purpurea (Fabaceae) da região Amazônica Artigo. Ouímica Nova, 37(1), 89-94.

Ehlermann, D. A. E. (2016). Particular applications of food irradiation: Meat, fish and others. Radiation Physics and Chemistry.

Farag, M. A., Sakna, S. T., El-Fiky, N. M., Shabana, M. M., \& Wessjohann, L. A. (2015). Phytochemical, antioxidant and antidiabetic evaluation of eight Bauhinia L. species from Egypt using UHPLC-PDA-qTOF-MS and chemometrics. Phytochemistry, 119, 41-50.

Farkas, J., \& Mohácsi-Farkas, C. (2011). History and future of food irradiation. Trends in Food Science \& Technology, 22(2-3), 121-126.

Ferreres, F., Gil-Izquierdo, A., Vinholes, J., Silva, S. T., Valentão, P., \& Andrade, P. B. (2012). Bauhinia forficata Link authenticity using flavonoids profile: Relation with their biological properties. Food Chemistry, 134(2), 894-904.

Ferreres, F., Llorach, R., \& Gil-Izquierdo, A. (2004). Characterization of the interglycosidic linkage in di-, tri-, tetra- and pentaglycosylated flavonoids and differ entiation of positional isomers by liquid chromatography/electrospray ionization tandem mass spectrometry. Journal of Mass Spectrometry, 39(3), 312-321.

Hallman, G. J. (2017). Process control in phytosanitary irradiation of fresh fruits and vegetables as a model for other phytosanitary treatment processes. Food Control, 72, 372-377.

Ihsanullah, I., \& Rashid, A. (2017). Current activities in food irradiation as a sanitary and phytosanitary treatment in the Asia and the Pacific Region and a comparison with advanced countries. Food Control, 72, 345-359.

Koike, A., Barreira, J. C. M., Barros, L., Santos-Buelga, C., Villavicencio, A. L. C. H., \& Ferreira, I. C. F. R. (2015a). Edible flowers of Viola tricolor L. as a new functional food: Antioxidant activity, individual phenolics and effects of gamma and electronbeam irradiation. Food Chemistry, 179, 6-14.

Koike, A., Barreira, J. C. M., Barros, L., Santos-Buelga, C., Villavicencio, A. L. C. H., \& Ferreira, I. C. F. R. (2015b). Irradiation as a novel approach to improve quality of Tropaeolum majus L. flowers: Benefits in phenolic profiles and antioxidant activity. Innovative Food Science and Emerging Technologies, 30, 138-144.

Kumar, N., Bhandari, P., Singh, B., \& Bari, S. S. (2009). Antioxidant activity and ultraperformance LC-electrospray ionization-quadrupole time-of-flight mass spectrometry for phenolics-based fingerprinting of Rose species: Rosa damascena, Rosa bourboniana and Rosa brunonii. Food and Chemical Toxicology, 47(2), 361-367.

Lakner, Z., Soos, S., Vida, Z., \& Farkas, C. (2016). European research and the Hungarian school of food irradiation. Radiation Physics and Chemistry, 129(SI), 13-23.

Liu, M., Dong, J., Lin, Z., Niu, Y., Zhang, X., Jiang, H., ... Chen, S. (2016). Rapid screening of transferrin-binders in the flowers of Bauhinia blakeana Dunn by on-line highperformance liquid chromatography-diode-array detector-electrospray ionizationion-trap-time-of-flight-mass spectrometry-transferrin-fluorescence detection sys. 
Journal of Chromatography A, 1450, 17-28.

Lorenzi, H., \& Matos, F. J. A. (2002). Plantas medicinais no Brasil: nativas e exóticas cultivadas. Medicina(2 ${ }^{\mathrm{a}}$ Ed.). Plantarum de Estudos da Flora 2002-512.

Marques, G. S., Leão, W. F., Lyra, M. A. M., Peixoto, M. S., Monteiro, R. P. M., Rolim, L. A., ... Soares, L. A. L. (2013). Comparative evaluation of UV/VIS and HPLC analytical methodologies applied for quantification of flavonoids from leaves of Bauhinia forficata. Brazilian Journal of Pharmacognosy, 23(1), 51-57.

Mlcek, J., \& Rop, O. (2011). Fresh edible flowers of ornamental plants - A new source of nutraceutical foods. Trends in Food Science and Technology, 22(10), 561-569.

Molins, R. A., Motarjemi, Y. K., \& Käferstein, F. K. (2001). Irradiation: A critical control point in ensuring the microbiological safety of raw foods. Food Control, 12(6), 347-356.

Moon, S., \& Song, K. Bin. (2001). Effect of gamma irradiation on the molecular properties of ovalbumin and ovomucoid and protection by ascorbic acid. Food Chemistry, 74(4), 479-483.

Pereira, E., Antonio, A. L., Barreira, J. C. M., Barros, L., Bento, A., \& Ferreira, I. C. F. R. (2015). Gamma irradiation as a practical alternative to preserve the chemical and bioactive wholesomeness of widely used aromatic plants. Food Research International, 67, 338-348.

Pereira, E., Antonio, A. L., Rafalski, A., Barreira, J. C. M., Barros, L., \& Ferreira, I. C. F. R. (2015). Extending the use of irradiation to preserve chemical and bioactive properties of medicinal and aromatic plants: A case study with four species submitted to electron beam. Industrial Crops and Products, 77, 972-982.

Pinheiro, T. S. D. B., Johansson, L. A. P., Pizzolatti, M. G., \& Biavatti, M. W. (2006). Comparative assessment of kaempferitrin from medicinal extracts of Bauhinia forficata Link. Journal of Pharmaceutical and Biomedical Analysis, 41(2), 431-436.

Pizzolatti, M. G., Cunha, A., Jr., Szpoganicz, B., Braz-filho, R., \& Schripsema, J. (2003). Flavonoids glycosides from leaves and flowers of Bauhinia forficata (Leguminosae). Química Nova, 26(4), 466-469.
Roberts, P. B. (2014). Food irradiation is safe: Half a century of studies. Radiation Physics and Chemistry, 105, 78-82.

Roberts, P. B. (2016). Food irradiation: Standards, regulations and world-wide trade. Radiation Physics and Chemistry, 129, 30-34.

Sagdic, O., Ekici, L., Ozturk, I., Tekinay, T., Polat, B., Tastemur, B., ... Senturk, B. (2013). Cytotoxic and bioactive properties of different color tulip flowers and degradation kinetic of tulip flower anthocyanins. Food and Chemical Toxicology, 58, 432-439. http://dx.doi.org/10.1016/j.fct.2013.05.021.

Salgueiro, A. C. F., Leal, C. Q., Bianchini, M. C., Prado, I. O., Mendez, A. S. L., Puntel, R. L., ... Puntel, G. O. (2013). The influence of Bauhinia forficata Link subsp. pruinosa tea on lipid peroxidation and non-protein SH groups in human erythrocytes exposed to high glucose concentrations. Journal of Ethnopharmacology, 148(1), 81-87.

Silva, M. C. C., De Paula, C. A. A., Ferreira, J. G., Paredes-Gamero, E. J., Vaz, A. M. S. F., Sampaio, M. U., ... Oliva, M. L. V. (2014). Bauhinia forficata lectin (BfL) induces cell death and inhibits integrin-mediated adhesion on MCF7 human breast cancer cells. Biochimica et Biophysica Acta - General Subjects, 1840(7), 2262-2271.

Taofiq, O., Calhelha, R. C., Heleno, S., Barros, L., Martins, A., Santos-Buelga, C., ... Ferreira, I. C. F. R. (2015). The contribution of phenolic acids to the anti-inflammatory activity of mushrooms: Screening in phenolic extracts, individual parent molecules and synthesized glucuronated and methylated derivatives. Food Research International, 76, 821-827.

Volpato, G. T., Damasceno, D. C., Rudge, M. V. C., Padovani, C. R., \& Calderon, I. M. P. (2008). Effect of Bauhinia forficata aqueous extract on the maternal-fetal outcome and oxidative stress biomarkers of streptozotocin-induced diabetic rats. Journal of Ethnopharmacology, 116(1), 131-137.

Xie, Y., \& Zhang, W. (2012). Antihypertensive activity of Rosa rugosa Thunb. flowers: Angiotensin i converting enzyme inhibitor. Journal of Ethnopharmacology, 144(3), $562-566$. 